\title{
ANALISIS KOMPILASI HUKUM ISLAM TENTANG TOLOK UKUR HIBAH YANG DIPERHITUNGKAN SEBAGAI WARISAN
}

\author{
Naviri Masma Rahmita dan Rachmad Budiono \\ Program Magister KenotariatanFakultas Hukum Universitas Brawijaya \\ JI. MT. Haryono No 169; Malang; 65145; Indonesia;(0341) 553898 \\ navirimasma@gmail.com
}

\begin{abstract}
Article 211 The Compilation of Islamic Law describes grants from parents to their children. The issues studied are what benchmarks grants from parents to their children can be counted as inheritance and what are the benchmarks of grants from parents to their children accounted for as grants. This research uses Legislation Approach with normative research type. The legal material of this research is primary, secondary and tertiary legal material. The results that can be concluded in the study of this journal are all gifts that parents give to their children that are not related to the cost of childcare, whether physical growth, spiritual and that pertains to the child's education then the gift is considered as an inheritance. While the benchmark of grants from parents to their children is taken into account as grants are all grants given to parents of parents to their children either giving related to the cost of childcare and education of children as well as gifts that are not related to the maintenance of children and also the education of children, whose nature does not expect the reward of the gift, then the gift is taken into account as a grant.
\end{abstract}

Keywords:Grants, Inheritanc,Inheritance Law.

\begin{abstract}
Abstrak
Pasal 211 Kompilasi Hukum Islam menjelaskan tentang hibah dari orang tua kepada anaknya. Permasalahan yang dikaji adalah apa yang menjadi tolok ukur hibah dari orang tua kepada anaknya dapat diperhitungkan sebagai warisan dan apa yang menjadi tolok ukur hibah dari orang tua kepada anaknya diperhitungkan sebagai hibah. Penelitian ini menggunakan Pendekatan Perundang-Undangan dengan jenis penelitian normatif. Bahan hukum penelitian ini adalah bahan hukum primer, sekunder dan tersier. Hasil yang dapat disimpulkan dalam kajian jurnal ini adalah segala pemberian yang diberikan orang tua kepada anaknya yang tidak berhubungan dengan biaya pemeliharaan anak, baik pertumbuhan jasmani, rohani maupun yang berhungungan dengan pendidikan sang anak maka pemberian tersebut diperhitungkan sebagai warisan. Sedangkan tolok ukur hibah dari orang tua kepada anaknya diperhitungkan sebagai hibah adalah segala pemberian yang diberika orang tua kepada anaknya baik pemberian yang berhubungan dengan biaya pemeliharaan anak dan pendidikan anak juga pemberian-pemberian yang sifatnya tidak berhubungan dengan pemeliharaan anak dan juga pendidikan anak, yang sifatnya tidak mengharapkan imbalan atas pemberian tersebut, maka pemberian tersebut diperhitungkan sebagai hibah.
\end{abstract}

Kata Kunci: HartaWarisan,Hibah,Hukum Waris. 
Peran Agama di Indonesia sangat penting dalam kehidupan masyarakat Indonesia. Agama Islam membawa perubahan sosial dan budaya, yakni memperhalus dan memperkembangkan budaya Indonesia. Sejarah masuknya hukum Islam di Indonesia bermula pada masa raja-raja Islam misalkan Sultan Agung dari Mataram yang memberlakukan hukum Islam secara memaksa. Kemudian pada saat Belanda datang dan menjajah Indonesia, perlahan hukum Islam dijauhkan, agar orang Islam menjauh dari keIslamannya. Salah satu cara agar hukum Islam tidak diberlakukan lagi adalah dengan mencabut kekuasaan Peradilan Agama di pulau Jawa dan pulau Madura untuk memerikasa, memutus dan menyelesaikan perkara kewarisan diantara orangorang yang beragama Islam (Budiono,1995).

Setelah Indonesia merdeka, keadaan tersebut tetap dilesatarikan. Banyak orang Islam yang sedikit menjauh dari keIslamannya. Akhirnya para ahli hukum Islam seperti Profesor Hazairin dan para ahli hukum Islam lainnya mulai menggali tentang hukum kewarisan Islam. Akhirnya lahirlah Instruksi Presiden Republik Indonesia Nomor 1 Tahun 1991, dan ditindaklanjuti oleh Keputusan Menteri Agama Republik Indonesia Nomor 154 Tahun 1991, kemudian dua produk hukum ini melahirkan Kompilasi Hukum Islam yang isinya membahas mengenai Perkawinan, Kewarisan, dan Perwakafan (Budiono,1995).

Kompilasi Hukum Islam membahas mengenai Perkawinan, Kewarisan dan Kewakafan. mengenai hal kewarisan di dalam nya juga dibahas mengenai Hibah. Banyak hal yang diatur oleh Kompilasi Hukum Islam, tulisan ini hanya akan membahas mengenai hibah, yaitu hibah orang tua kepada anak.Hibah diatur dalam Kompilasi Hukum Islam yaitu dalam Pasal 210 sampai dengan Pasal 214. Pengertian hibah menurut Pasal 171 Huruf g Kompilasi Hukum Islam adalah "pemberian dari sesorang kepada orang lain yang masih hidup secara sukarela dan tanpa imbalan untuk dimiliki". Berdasarkan Pasal 171 Huruf g tersebut diatas, hibah merupakan pemberian dan bukan merupakan pinjaman seperti orang yang mengizinkan untuk mempergunakan atau memanfaatkan suatu benda tertentu. Hibah juga mendatangkan kesenangan bagi orang yang menerimanya (Sarmadi, 2013).

Memperkuat isu hukum yang sedang diteliti, maka dalam tulisan ini penulis akan mengambil contoh kasus terkait dengan masalah hibah dari orang tua kepada anaknya. Sebagai salah satu contoh adalah Putusan Pengadilan Agama Republik Nomor 13/Pdt.G/2012/P.A.Pts. Kasus tersebut para ahli waris menuntut untuk pembagian warisan secara adil karena sebelumnya juga telah dibagikan hibah kepada para ahli wais. Namun, dalam pertimbangan hakim tidak dijelaskan secara jelas alasan mengapa hibah tersebut diperhitungkan sebagai warisan, dimana pertimbangan hakim tersebut menyatakan bahwa:" maka sesuai bunyi Pasal 211 Kompilasi Hukum Islam disebutkan "hibah dari orang tua kepada anaknya dapat diperhitungkan sebagai warisan", maka berdasarkan Pasal tersebut, ahli waris yang telah menerima pemberian atau hibah dari orang tuanya diperhitungkan sebagai waisan" (Putusan Pengadilan Agama 13/ Pdt.G/2012/P.A.Pts).

Baik dalam penjelasan Pasal 211 Kompilasi Hukum Islam maupun pertimbangan hakim dalam putusan nomor 13/Pdt.G/2012/P.A.Pts, tidak dijelaskan secara jelas kapan hibah tersebut diperthitungkan sebagai warisan dan kapan hibah tersebut tidak dipeprhitungkan sebagai warisan. Mengingat permasalahan tentang hibah dari orang tua kepada anaknya ini merupakan permasalahan dalam lingkungan keluarga, maka dari itu permasalahan-permasalahan seperti ini diharapakan agar tidak sampai merusak tali persaudaraan dalam suatu keluarga. Karena sejatinya harta dapat membutakan siapa saja. Melihat apa yang dijelaskan pada latar belakang yang telah diuraikan diatas, maka penulis menarik rumusan masalah, yaitu; Apa yang menjadi tolok ukur hibah dari 
orang tua kepada anaknya diperhitungkan sebagai warisan dan Apa yang menjadi tolok ukur hibah dari orang tua kepada anaknya diperhitungkan sebagai hibah.

\section{Metode Penelitian}

Penelitian ini adalah penelitian hukum yang lazim disebut penelitian hukum normatif, karena mengkaji secara yuridis Pasal 211 Kompilasi Hukum Islam. Metode penelitian hukum normatif adalah suatu prosedur penelitian ilmiah untuk menemukan kebenaran berdasar logika keilmuan hukum dari sisi normatifnya (Ibrahim,2007). Dasarnya suatu penelitian normatif tentu harus menggunakan pendekatan Perundang-Undangan, karena yang akan diteliti adalah aturan hukum yang menjadi fokus sekaligus tema sentral suatu penelitian. Namun dalam hal ini peneliti tidak hanya akan menggunakan satu pendekatan, peneliti akan menggunakan pendekatan lainnya yaitu pendekatan analitis.

Memecahkan isu hukum dan sekaligus memberikan preskripsi mengenai apa yang seyogianya, diperlukan sumber-sumber penelitian. Sumbersumber penelitian hukum dapat dibedakan menjadi sumber-sumber penelitian yang berupa bahanbahan hukum primer, bahan-bahan hukum sekunder dan bahan- bahan hukum tersier(Marzuki, 2007).

Bahan-bahan hukum dalam ini berupa: Undang-Undang Republik Indonesia Nomor 12 Tahun 2011 tentang Pembentukan Peraturan Perundang-Undangan, Instruksi Presiden Republik Indonesia Nomor 1 Tahun 1991 tentang Kompilasi Hukum Islam, Kitab Undang-Undang Hukum Perdata, Putusan Pengadilan Agama Nomor: 13/ Pdt.G/2012/P.A.Pts, Keputusan Bersama Ketua Mahkamah Agung Republik Indonesia dan Menteri Agama Republik Indonesia Nomor: 07/MKA/1985 dan No. 25 Tahun 1985 tentang Penunjukan Pelaksanaan Proyek Pembangunan Hukum Islam melalui
Yurisprudensi, Surat Edaran Biro Peradilan Agama No.B./1/735 (tindak lanjut dari Peraturan Presiden Republik IndonesiaNo.45 Tahun 1958 tentang Pembentukan Pengadilan Agama/Mahmakah Syari'iyay di luar Jawa dan Madura, Tap No./ MPRS/1996 Tentang Memorandum DPR-GR Mengenai Sumber Tertib Hukum Republik Indonesia dan Tata Urutan Peraturan Perundangan Republik Indonesia.

Teknik analisis bahan hukum yang digunakan untuk menyelesaikan permasalahan yang diangkat dalam penelitian ini adalah Interprestasi sistematis. Hal iniditujukan untuk menafsirkan dengan memperhatikan naskah-naskah hukum lain. Jika ditafsirkan adalah Pasal-Pasal suatu UndangUndang, ketentuan yang sama apalagi satu asas dalam peraturan lainnya juga dijadikan acuan.

Penafsiran ini mencari ketentuan-ketentuan yang ada didalamnya saling berhubungan sekaligus apakah hubungannya menentukan makna selanjutnya (Asshiddiqie, 1997). Teknik analisa ini digunakan untuk menganalisis tolok ukur hibah yang diperhitungkan sebagai warisan.

\section{Tolok Ukur Hibah dari Orang Tua Kepada Anaknya Diperhitungkan Sebagai Warisan}

Pengertian hibah dan warisan sangat berbeda. Menurut pengertian bahasa, hibah berarti mutlak pemberian, baik berupa harta benda maupun yang lainnya (Chasana, 2014). Apabila pemberian itu tidak dimaksudkan untuk menghormati, memuliakan atau bukan karena dorongan cinta, tidak pula dimaksudkan untuk memperoleh ridha Allah dan mendapatkan pahalanya, maka pemberian itu dimanakan hibah. Bila pemberian itu dimaksudkan untuk menghormati memuliakan kepada orang yang diberinya atau karena motivasi cinta maka dinamakan hadiah. Apabila pemberian itu dimaksudkan untuk mendapat ridha Allah dan pahalanya atau karena menutup kebutuhan orang 
yang diberinya maka dinamakan sedekah atau sadaqah (Ramulyo, 1994).

Warisan atau dalam kata lain juga sering disebut dengan iris, miratis, turats, dan tirkah adalah sesuatu yang ditinggalkan oleh orang yang meninggal dunia, baik berupa benda bergerak maupun benda tidak bergerak, dalam kepustakaan (Ria, 2008). Penjelasan mengenai perbedaan hibah dan warisan diatas, terkait dengan Pasal 211 Kompilasi Hukum Islam yang menyatakan bahwa "Hibah dari orang tua kepada anaknya dapat diperhitungkan sebagai warisan", maka, pengertian hibah tidak sama dengan pengertian warisan.

Bila berbicara mengenai hibah dari orang tua kepada anaknya hal ini mengingatkan pada sabda Nabi Muhammad SAW. "bersikaplah adil terhadap anak-anakmu, adil terhadap anak-anakmu, bersikaplah adil terhadap anak-anakmu"(HR. Abu Daud), (Sijistani, 1995).

Prinsipnya pelaksanaan hibah orang tua kepada anak sesuai dengan petunjuk Rasulullah SAW. hendaknya bagian untuk anak-anak mereka itu disamakan. Jika menghendaki untuk dibedakan maka hal tersebut hendaknya dilakukan dengan saling menyetujui satu sama lain. Hal semacam ini dianggap penting agar nantinya tidak timbul suatu masalah yang dapat menimbulkan perpecahan dalam keluarga.

Ada beberapa pendapat tentang penghibahan harta yang dimiliki kepada seseorang. Imam Ahmad, Ishak, dan para pengikut Maliki tidak menghalalkan seseorang untuk memberi hartanya tidak sama antara anak satu dengan yang lainnya. Bahkan pengikut Imam mengharap keadaan seperti itu. Pendapat lain mengatakan bahwa pemberian yang disama ratakan itu adalah sunah, dan apabila dilebihkan kepada salah satu dari anaknya maka hal tersebut hukumnya makruh. Lain halnya pendapat dari Jumhur Ulama, bahwa seseorang boleh menghibahkan seluruh harta yang dimiliki. Sedangkan menurut Muhammad Ibnu Hasan berpendapat bahwa tidak sah apabila menghibahkan seluruh hartanya meskipun hal tersebut adalah untuk kebaikan (Shomad,1999).

Nabi Muhammad SAW bersabda:" telah menceritakan kepada kami Utsman dan Abu Bakar, keduanya anak Abu Syaibah, secara makna mereka berkata; telah menceritakan kepada kami Abu Mu'awiyah dari Abu Malik Al Asyja'i dari Ibnu Hudair dari Ibnu Abbas ia berkata," Rasulullah SAW. bersabda: "Barang siapa memiliki anak perempuan (atau saudara perempuan), ia tidak menguburkannya hidup-hidup, tidak menghinakannya, dan tidak melebihkan anak laki-laki di atas mereka, maka Allah akan memasukkan dia ke dalam surga." Utsman tidak menyebut lafadz "laki-laki". H.R. Abu Daud (Sarmadi, 2013). Berikutnya: "Persamakanlah anak-anakmu didalam pemberian, seandainya aku hendak melebihkan seseorang, tentunya aku akan melebihkan anak-anak perempuan" H.R. Thabrani dan Baihaqi (Sarmadi, 2013).

Berdasarkan sabda Nabi SAW tersebut diatas, ternyata hal ini yang menjadikan Imam Ahmad dan Ats Sauri untuk mengharamkan melebihkan pemberian kepada salah seorang anak saja. Mazhab Syafi'i, Maliki menyatakan bahwa hal tersebut adalah makruh dan beranggapan bahwa tidak melebihkan pemberian itu sifatnya sunah dan bukan merupakan kewajiban yang harus dilaksanakan.

Imam Al Syafi'i menyatakan bahwa tidak memperbolehkan bagi seseorang boleh berbicara tentang halal dan haram tanpa ada dasar ilmu. Pedoman Imam al-Syafi'i dalam menetapkan hukum adalah Al-Qur'an, hadits, ijma', dan qiyas. Hal ini sesuai dengan peristiwa Muadz Bin Jabal ketika dia diutus Nabi menjadi gubernur di Yaman, sebagaimanadinukilkandalamHadits:

"dari Abi 'Aun dari al Haris bin Umar bin Akhi al Mughirah bin Syu'bah dari Anas dari sahabat Muadz bin Jabal bahwasanya Rasulullah SAW ketika hendak mengutus Muadz ke Yaman beliau bertanya: bagaimana engkau memutuskan ketika dihadapkan pada sebuah pertanyaan? Muadz menjawab: aku akan memutuskan dengan kitab Allah, Nabi SAWbertanya: apabila engkau tidak menemukan dalam kitab Allah? Muadz menjawab: 
maka dengan Rasulullah SAW, Nabi bertanya lagi: apabila engkau tidak menemukan dalam hadits Nabi SAW dan Kitab Allah? Muadz menjawab: maka aku akan berijtijhad dengan pendapatku dan tidak berlebihan. Kemudian Nabi SAW menepuk dada Muadz sambil berkata: segala puji bagi Allah yang telah menolong utusan Rasul SAW pada sesuatu yang telah dirihai Rasulullah" (Sijistani,1995).

Ketika terjadi permasalahan yang ditanyakan pada Muadz pertama kali yang akan dia lakukan untuk mencari jawaban dari suatu permasalahan itu adalah dicarinya dalam Al-Qur' an, jika tidak ditemukan maka akan dicari dalam hadits-hadits Nabi Saw tentang ketentuan hukumnya. Apabila sudah ditemukan ketentuan hukumnya dalam al Qur'an maka Muadz tidak akan mencari dalam hadits.

Begitu juga jalan ijtihad yang ditempuh oleh Imam Syafi'i. Ketika beliau berijtihad atau mengistinbathkan hukum maka jalan yang pertama kali ditempuh adalah mencari jawaban dalam AlQur'an, ketika tidak ditemukan dalam Al-Qur'an maka akan mencarinya lagi pada sumber yang kedua, yaitu hadits, ketika masih belum ditemukan ketentuan hukumnya, maka akan mencari dalam ijma' para sahabat, ketika dalam ijma' tidak ditemukan pula, maka Imam syafi'i menggunakan qiyas (analogi).

Al-Qur'an merupakan kitab suci yang diturunkan Allah berupa wahyu yang diturunkan kepada Nabi Muhammad SAW semasa hidupnya. Al-Qur' an memuat ajaran tentang akidah, syaria' ah, akhlak, kisah umat dimasa lalu dan juga kehidupan di akhirat. Al-Qur'an juga diatur mengenai prinsip ilmu dan prinsip hukum yang bermanfaat bagi manusia nantinya(Purbasari, 2017).Sunnah dapat berupa perkataan, perbuatan bahkan sikap diam Rasulullah Muhammad SAW. Sunnah berfungsi menjelaskan mengenai ketentuan-ketentuan pokok yang ada di dalam Al-Qur'an dan melengkapi serta menafsirkan apa yang belum disebut dalam AlQur'an(Purbasari, 2017).
Ijtihad merupakan pemikiran manusia dalam menafsirkan kaidah dalam Al-Qur'an dan Sunnah. Hal ini hanya boleh dilakukan oleh orang yang memiliki pengetahuan yang luas dan mendasar mengenai kaidah Hukum Islam dalam Al-Qur'an dan Sunnah. Ada sekitar tujuh metode dalam melakukan ijtihad menurut Muhammad Daud Ali, yaitu; (1) Ijma', Ijma' adalah kesepakatan ulama atau mujtahid terhadap suatu persoalan yang dibahas. (2) Qiyas, Qiyas adalah alat untuk menemukan hukum suatu persoalan yang baru dengan membandingkan unsur/sebab/perihal kesamaan terhadap persoalan baru dan persoalan lama kemudian ditarik hukum yang sama atas dasar kesamaan perihal. (3) Illat, Secara terminologis illat adalah suatu sifat yang berfungsi sebagai pengenal bagi suatu hukum. (4) Istihsan, Istihsan sebagai cara memperoleh suatu hukum dengan mengesampingkan analogi dan ketentuan baku yang ada demi kepentingan masyarakat dan keadilan. (5) Maslahah mursalah, Maslahah musrsalah adalah prinsip atau suatu perbuatan yang mengandung nilai kemanfaatan. (6) Istishab, Istishab adalah menetapkan hukum sesuatu hal menurut keadaan yang terjadi sebelumnya, sampai ada dalil yang mengubahnya. (7) Uruf, Urufsering dikaitkan dengan adat istiadat atau kebiasaan masyarakat setempat yang tetap dapat berlaku selama tidak bertentangan dengan syariah (Purbasari, 2017).

Kesemua metode ijtihad tersebut diatas, metode ijma' dan qiyas yang paling dikenal di Indonesia (Purbasari, 2017). Berangkat dari pendapat di atas, maka hukum perdata Islam Indonesia mengambil jalan tengah yang menyatakan bahwa hibah tersebut harus dihitung sebagai warisan. Artinya dalam hal ini seseorang boleh saja menghibahkan sebagian hartanya kepada anaknya, namun harus diperhitungkan sebagai bagian dari warisan. Apabila ia meniggal dunia, maka hibah tersebut dimasukkan ke dalam bundel warisan dengan memperhitungkan bahwa bagian dari warisan untuk anak yang telah mendapat hibah akan dipotong jumlahnya sesuai dengan jumlah 
hibah yang diberikan kepadanya sewaktu pemberi hibah itu masih hidup (Purbasari, 2017).

Hibah yang diberikan orang tua kepada anaknya, ternyata dikemudian hari dapat menimbulkan masalah antara ahli waris yang ditinggalkan. Kenyataan sampai saat ini masih banyak ahli waris yang menuntut agar ditetapkan pembagian warisan yang terkait dengan hibah yang sebelumnya telah diberikan oleh orang tua. Salah satu contoh yang telah dijelaskan sebelumnya adalah Putusan Pengadilan Agama Nomor 13/Pdt.G/2012/P.A.Pts. Kasus tersebut para ahli waris menuntut untuk pembagian warisan secara adil karena sebelumnya juga telah dibagikan hibah kepada para ahli wais. Pertimbangan hakim tersebut menyatakan bahwa: "maka sesuai bunyi Pasal 211 Kompilasi Hukum Islamdisebutkan" hibah dari orang tua kepada anaknya dapat diperhitungkan sebagai warisan", maka berdasarkan Pasal tersebut, ahli waris yang telah menerima pemberian atau hibah dari orang tuanya diperhitungkan sebagai waisan" (Putusan Pengadilan Agama 13/Pdt.G/2012/P.A.Pts).

Mengenai hibah dari orang tua dapat diperhitungkan sebagai warisan, pernyataan ini terdapat dalam Kompilasi Hukum Islam. Kompilasi Hukum Islam merupakan ijtihad para ahli hukum Islam. Dilihat dari fungsinya, ijtihad memiliki tiga fungsi, yaitu;:

1. Ijtihad terhadap nashzhanny, Ijtihad ini dalam persoalan yang sudah ada, tetapi pengertiannya nya bersifat ganda.

2. Ijtihad terhadap nash qath'i, Ijtihad ini untuk menghadapi persoalan yang hukumnya secara jelas terdapat dalam nashqath'i, maka tidak ada keterbukaan bagi manusia untuk berijtihad, khusus dalam bidang kewarisan.

3. Ijtihad dalam persoalan yang tidak ada dalam nash Dalami jtihad ini, umat Islam diberi keleluasaan, tetapi tidak melenceng dari Al-Qur'an dan Sunnah untuk dapat disesuaikan dengan kondisi masyarakat karena adanya perubahan sosial. Ijtihad ini didapat melalui dasar pertimbangan dengan alur metodologis sebagai sarana untuk memperoleh hukum kewarisan khususnya. Metode-metode itu antara lain melalui ijma', deduksi analogi (qiyas), adat istiadat, maslahah dan darurat (Anshori, 2012).

Bila dikaitkan antara ijtihad para ahli hukum Islam dengan Pasal 211 Kompilasi Hukum Islam ini terlihat bahwa ijtihad yang dilakukan adalah ijtihad dalam persoalan yang tidak ada dalam nash. Bila dianalisis lebih lanjut, Pasal 211 Kompilasi Hukum Islam memuat aspekurf, karena setelah melihat nash, baik itu Al-Qur'an maupun Hadist, tidak menjumpai nash yang menunjukkan tentang diperhitungkannya hibah orang tua kepada anak sebagai warisan.

Hibah tersebut merupakan adat kebiasaan yang telah mengakar dan telah diterima oleh masyarakat Indonesia. Adat istiadat semacam ini menurut kaidah-kaidah Hukum Islam disebut $u r f$. Urf adalah segala sesuatu yang sudah dikenal oleh manusia, yang telah menjadi kebiasaan atau tradisi, baik bersifat perkataan, perbuatan atau dalam kaitannya dengan meninggalkan perbuatan tertentu.

Berikut akan dijelaskan macam-macam Urf. Apabila ditinjau dari segi jangkauannya Urfdapat dibagi menjadi (Dahlan\& Rahman, 2011):

1. Al- 'Urfal-Amm (Adat kebiasaan umum), Yaitu kebiasaan yang bersifat umum dan berlaku bagi sebagian besar masyarakat dalam berbagai wilayah yang luas.

2. Al-'Urf al-Khashsh (Adat kebiasaan khusus), Yaitu adat kebiasaan yang berlaku secara khusus pada suatu masyarakat tertentu, atau wilayah tertentu saja.

Diatas telah dijelaskan mengenai Urf bila ditinjau dari segi jangkauannya, sendangkan apabila ditinjau dari segi ketentuan hukumnya, maka ia pun terbagi dua: (1) Al-'Urfash-Shahih ('Urf yang absah), Yaitu sesuatu yang telah saling dikenal oleh 
manusia dan tidak bertentangan dengan dalil syara', tidak menghalalkan yang haram dan tidak juga membatalkan yang wajib. (2) Al-'Urf al-Fasid ('Urf yang rusak/salah), Yaitu sesuatu yang telah saling dikenal manusia, tetapi bertentangan dengan syara', atau menghalalkan yang haram dan membatalkan yang wajib (Dahlan\& Rahman, 2001).

Ahmad Azhar Basyir dalam persoalan relevansi urf dengan Al-Qur'an atau hadis, menjelaskan bahwa syarat suatu urf dapat dijadikan sebagai suatu sumber hukum ijtihad salah satunya adalah apabila urf tersebut tidak bertentangan dengan nash (Al-Qur' an ataupun Hadis). Oleh karena itu, untuk menilai apakah sesuatu urf bertentangan dengan nash atau tidak, perlu diadakan pengkajian dengan seksama.

Penetapan hukum tidak bisa terlepas dari hukum adat dibagi kedalam empat prinsip, yaitu:

1. Hukum Islam melegalisir hukum adat untuk berlaku seterusnya. Hal ini jika hukum adat tersebut tidak bertentangan dengan hukum Islam. dalam hal ini hukum adat berlaku jika telah diresepsi oleh hukum Islam, bukan sebaliknya hukum Islam beru berlaku jika diresepsi hukum adat.

2. Hukum Islam menerima hukum adat pada hal yang prinsip, kendatipun dalam pelaksanaannya berbeda dan karenanya harus disesuaikan.

3. Hukum Islam lebihb diutamakan dibandingkan dengan hukum adat jika terjadi perbedaan prinsip antara hukum Islam dengan hukum adat.

4. Islam menolak terhadap hukum adat lama karena adat itu tidak sesuai dengan hukum Islam, terutama jika memperhatikan terhadap kemaslahatan dan kemudlaratan yang ditumbulkan oleh hukum adat itu(Anshori,2012).

Proses pembagian warisan menurut Hilman Hadikusuma dapat dilaksanakan pada: (1) Sebelum pewaris meninggal dunia (masih hidup) dengan cara penerusan atau pengalihan, penunjukan, pesan atau wasiat. (2) Setelah pewaris meninggal dunia, pemberian harta sesudah pewaris meninggal dunia merupakan proses yang universal dalam setiap hukum waris adat (Afrizal, 2015).

Terkait mengenai hibah yang dapat diperhitungkan sebagai warisan yang memuat aspek adat istiadat, disini bukan Kompilasi Hukum Islam yang menyesuaikan dengan adat. Tetapi adat tersebut telah diresepsi oleh hukum Islam, sehingga Pasal tersebut membuat aspek hukum adat yang telah direspsi oleh hukum Islam. sebagai contoh pada masyarakat jawa yang juga menganut pembagian warisan saat masih hidup. Pemberian tersebut sebagai warisan yang sudah diberikan ketika calon pewaris masih hidup (Anshori,2012).

Waris dan hibah menunjukkan adanya perbedaan dan persamaan, namun dalam fakta di masyarakat hibah dan warisan menjadi sesuatu yang tidak dipisahkan. Menurut hukum adat, hibah kepada yang berhak atas warisan dipandang sebagai kewarisan yang telah dilaksanakan pada waktu pewaris masih hidup (Basyir, 2001).

Ketentuan dalam Pasal 211 Kompilasi Hukum Islam tersebut perlu diperjelas lagi mengenai tolok ukur hibah yang diperhitungkan sebgai warisan. Mengenai hibah yang dapat diperhitungkan sabagai warisan, dalam Kitab Undang-Undang Hukum Perdata dikenal dengan istilah inbreng, inbreng adalah pemasukan kembali ke dalam harta peninggalan, hibah-hibah atau pemberian-pemberian si peninggal warisan ketika masih hidup (Tanuwidjaya, 2012).

Kitab Undang-Undang Hukum Perdata Pasal 1086 sampai dengan Pasal 1096 ditegaskan: (1) Semua hibah (schengkingen) oleh si pewaris (peninggal warisan) ketika masih hidup. (2) Segala sesuatu yang telah diberikan kepada ahli waris. (3) Segala yang telah diberikan kepada ahli waris untuk memberikan kedudukan dalam masyarakat atau satu jabatan atau pekerjaan kepada ahli waris. (4) Segala sesuatu yang dimasukkan untuk membayar utangutang si ahli waris. (5) Segala sesuatu yang merupakan pesangon perkawinan. 
Pasal 1097 Kitab Undang-Undang Hukum Perdata ada yang tidak dimasukkan yaitu: (1) Biaya pemeliharaan dan pendidikan ahli waris. (2) Tunjangan untuk penghidupan yang seperlunya. (3) Biaya belajar guna perdagangan, kerajinan tangan, kebudayaan dan perusahaan. (4) Biaya perkawinan, perhiasan pakaian untuk perlengkapan perkawinan. Namun ketentuan diatas perlu dianalisis lagi terkait hibah yang diperhitungkan sebagai warisan sesuai dengan ketentuan Pasal 211 Kompilasi Hukum Islam.

Jika dianalisis lebih lanjut mengenai ketentuan tersebut maka yang ada hubungannya antara orang tua dengan anaknya hanyalah terbatas pada biaya pemeliharaan dan pendidikan sang anak dan juga tunjangan untuk penghidupan yang seperlunya. Perkawinan dan segala perlengkapan yang diberikan, bila dilihat dari segi hukum Islam yang memberikan perhiasan dan lain sebagainya yang berhubungan dengan perkawinan adalah mempelai pria. Hal ini kaitannya dengan calon mempelai bukan antara orang tua dan anakmya.

Kewajiban orang tua kepada anaknya dalam Islam termuat dalam Pasal 77 Ayat (3) Kompilasi Hukum Islam, dimana kewajiban orang tua adalah wajib mengasuh dan memelihara dan juga mendidik anak-anak mereka dengan sebaik-baiknya, baik mengenai pertumbuhan jasmani, rohani maupun kecerdasannya dan pendidikan agamanya. Kemudian dalam Pasal 80 Ayat (4) Kompilasi Hukum Islam juga menyebutkan kewajiban seorang ayah selaku orang tua adalah menanggung biaya perawatan, biaya pengobatan dan menanggung biaya pendidikan sang anak. Pasal tersebut diatas, kewajiban orang tua kepada anaknya adalah memberikan pendidikan dan penghidupan yang layak bagi anaknya sesuai dengan kemampuannya. Hal tersebut wajib diberikan kepada anak karena merupakan hak anak untuk mendapatkan pendidikan dan penghidupan yang layak sesuai kemampuan orang tua.
Sedangkan mengenai penghidupan yang layak untuk anak, orang tua berkewajiban untuk menanggungnya. Seorang ayah bertanggungjawab memberikan nafkah bagi anak-anak dan keluarganya, sedang ibu bertanggungjawab mengasuh anak-anak dan mengatur rumah tangga sebagai wakil dari suaminya.Tentang besarnya nafkah untuk anak dan keluarganya ini Islam tidak menentukan besarnya secara khusus, hal ini terserah pada kemampuan masing-masing.

Firman Allah SWT:" Kaum laki-laki itu adalah pemimpin bagi kaum wanita, karena Allah telah melebihkan sebagianmereka (laki-laki) atas sebagian yang lain (wanita), dan karena laki-laki telah menafkahkan sebagian dari hartamereka..."(QS. An-Nisaa:34).

Demikian pula difirmankan: "dan bagi ayah berkewajiban memberi nafkah dan memberi pakaian kepada ibu (dan anaknya) dengancarayang ma'ruf' (QS. Al-Baqarah:233).

Berikutnya: "Hendaklah orang yang mampu memberi nafkah menurut kemampuannya.Dan orang yang disempitkan rezqinya hendaklah memberi nafkah dari harta yang Allah berikan kepadanya.Allah tidak memikulkan beban kepada seseorang melainkan (sekedar)apayang Allah berikan kepadanya. Allah akanmemberikan kelapangan sesudah kesempitan" (QS. Ath-Thalaaq: 7).

Penjelasan-penjelasan diatas bahwa pemberianpemberian tersebut merupakan seuatu kewajiban dan tanggung jawab bagi orang tua terhadap anaknya. Sehingga yang tidak perlu dimasukkan ke dalam harta peninggalan atas hibah-hibah atau pemberian-pemberian si peninggal warisan ketika masih hidup adalah biaya pemeliharaan anak, baik pertumbuhan jasmani, rohani, maupun pendidikan bagi sang anak.

Pembahasan ini mencari jawaban atas kekaburan norma yang terjadi pada Pasal 211 Kompilasi hukum Islam. Berbagai penjelasan diatas, maka dapat di kerucutkan mengenai tolok ukur hibah 
dari orang tua yang dapat diperthitungkan sebagai warisan, yaituWujud warisan dalam hukum Islam adalah harta benda dan juga segala hak dari seseorang yang telah meninggal dunia dalam keadaan bersih. Sehingga apabila hibah diperhitungkan sebagai warisan. Sedangkan tolok ukur hibah dari orang tua kepada anaknya yang dapat diperhitungkan sebagai warisan itu adalah segala pemberian yang diberikan orang tua kepada anaknya yang tidak berhubungan dengan biaya pemeliharaan anak, baik pertumbuhan jasmani, rohani, maupun pendidikan sang anak, maka pemberian tersebut diperhitungkan sebagai warisan.

\section{Tolok Ukur Hibah dari Orang Tua Kepada Anaknya Diperhitungkan Sebagai Hibah}

Hukum Islam yang berlaku merupakan hukum yang mempunyai karakteristik demokratis, pluralis, dengan karakteristiknya yang sempurna, universal, dinamis dan sistematis (Djamil, 1997). Istilah waris dalam Islam disebut juga dengan fara'id yaitu bentuk jamak dari faridhah yang secara harfiyah berarti bagian yang telah ditentukan. Pengertian ini erat kaitannya dengan fardu yang berarti kewajiban yang harus dilaksanakan (Praja, 1995). Sehingga dalam kata lain hukum kewarisan dalam Islam merupakan suatu kewajiban yang harus dilaksanakan oleh setiap muslim dan berlaku mutlak. Hukum kewarisan Islam secara langsung diatur dalam Al-Qur'an dan Sunnah. Selain diatur dalam Al-Qur'an dan Sunnah, hukum kewarisan Islam juga diatur dalam Kompilasi Hukum Islam yang merupakan ijtihad para ulama.

Pengertian hibah menurut Pasal 171 Huruf g Kompilasi Hukum Islam adalah "pemberian suatu benda secara sukarela dan tanpa imbalan dari seseorang kepada orang lain yang masih hidup untuk dimiliki". Bedasarkan Pasal 171 Huruf $\mathrm{g}$ tersebut diatas, hibah merupakan pemberian dan bukan merupakan pinjaman seperti orang yang mengizinkan untuk mempergunakan atau memanfaatkan suatu benda tertentu. Hibah juga menda- tangkan kesenangan bagi orang yang menerimanya (Sarmadi, 2013).

Ketentuan lain tentang hibah dalam Pasal 210 Kompilasi Hukum Islam menyebutkan bahwa: “Orang yang telah berumur sekurang-kurangnya 21 Tahun, berakal sehat dan tanpa adanya paksaan dapat menghibahkan sebanyak-banyaknya 1/3 bagian harta bendanya kepada orang lain atau lembaga dihadapan dua orang saksi untuk dimiliki. Dan harta benda yang dihibahkan harus merupakan hak dari penghibah."Segala macam harta benda yang dapat dijadikan hak milik dapat dihibahkan, baik harta pusaka maupun harta gono-gini seseorang, benda tetap maupun benda bergerak dan segala macam piutang serta hak-hak yang tidak berwujud itu pun dapat dihibahkan oleh pemiliknya (Rusyd,1999).

Jika pemberian tersebut dilakukan dalam bentuk tertulis, bentuk terseut terdapat dua macam, yaitu; (1) Bentuk tertulis yang tidak perlu didaftarkan, jika isinya hanya menyatakan telah terjadinya pemberian. (2) Bentuk tertulis yang perlu didaftarkan, jika surat itu merupakan alat dari penyerahan pemberian itu sendiri, artinya apabila pernyataan dan penyerahan benda yang bersangkutan kemudian disusul oleh dokumen resmi tentang pemberian, maka yang demikian itulah yang harus didaftarkan (Suparman, 2005).

Seorang hendak menghibahkan sebagian atau seluruh harta kekayaannya semasa hidupnya, dalam Hukum Islam harus memenuhi persyaratan sebagai berikut (Sarmadi, 2013): (1) Orang tersebut harus sudah dewasa, (2) Harus waras pikirannya, (3) Orang tersebut harus sadar dan mengerti tentang apa yang diperbuatnya, (4) Perempuan ataupun laki-laki dapat melakukan perbuatan hibah.

Terdapat tiga syarat yang harus dipenuhi dalam hal melakukan hibah menurut hukum Islam ini, yaitu sebagai berikut; (1) Ijab, yaitu pernyataan tentang pemberian tersebut dari pihak yang memberikan, (2) Qabul, yaitu pernyataan dari pihak yang menerima pemberian hibah itu, (3) Qabdlah, yaitu penyerahan milik itu sendiri, baik dalam 
bentuk yang sebenarnya maupun secara simbolis (Suparman, 1985).

Selain pendapat diatas, mazhab Hanabilah menyebutkan bahwa rukun hibah ada 3 (tiga), yaitu; (1) Orang-orang yang Berakad ('Aqidain), (2) Harta yang Dihibahkan (Al-Mauhub), (3) Silat(Ijab - Qabul) (Al-Jaziri,2007).Kemudian syarat untuk menjalankan rukun hibah yang disebutkan di atas, diperjelas lagi sebagai berikut:

a. Syarat Bagi Pemberi Hibah (Al-Wahib), yaitu: (Aziz, 2008) Al-Wahibmerupakan pemilik dari barang yang dihibahkan, Bali!,merdekadan berakal, Pemeberian haruslah atas dasar keinginan sendiri, bukan paksaan.

b. Syarat Bagi Penerima Hibah (Al-Mauhub Lah), yaitu: (Sabiq, 2006) Penerima hibah harus benarbenar maujud secara fisik atau diketahui keberadaannya saat pemberian hibah. Jika berupa fisik keberadaannya masih dalam prediksi, misalnya janin yang ada dalam kandungan, maka hibah tidak sah. Kamudian jika penerima hibah dianggap tidak mumuayyiz, maka boleh diserahkan melalui walinya.

c. Syarat Harta yang Dihibahkan (Al-Mauhub), yaitu: (Rusyd,1999) Harta yang dihibahkan ada ketika akad berlangsung, Harta merupakan milik orang yang mengihbahkan, Harta itu bernilai menurut syara', Dapat dimiliki hartanya, Harta itu dikhususkan agar jelasdzat-nya.

d. SyaratSi!at(Ijab - Qabul), dalam hal ini harus ada kesesuaian antara Ijab dan Qabul sebagai syarat yang paling utama.

Penjelasan-penjelasan mengenai hibah seseorang kepada orang lain hal itu sama hal nya dengan hibah yang diberikan orang tua kepda anaknya. Bahwa pemberian yang diberikan harus memenuhi syarat untuk dapat dikatan hibah. Apabila sebelumnya telah dijelaskan mengenai tolok ukur hibah dari orang tua diperhitungkan sebagai warisan adalah segala pemberian yang diberikan orang tua kepada anaknya adalah segela pemberian yang tidak berhubungan dengan biaya pemelihara- an anak, baik pertumbuhan jasmani, rohani, maupun pendidikan sang anak, maka pemberian tersebut diperhitungkan sebagai warisan.

Dengandemikian dipahamibahwa tolok ukur hibah dari orang tua kepada anaknya diperhitungkan sebagai hibah adalah segala pemberian yang diberikan orang tua kepada anaknya baik pemberian yang berhubungan dengan biaya pemeliharaan anak dan pendidikan anak juga pemberianpemberian yang sifatnya tidak berhubungan dengan pemeliharaan anak dan juga pendidikan anak, yang sifatnya tidak mengharapkan imbalan atas pemberian tersebut,maka pemberian tersebut diperhitungkan sebagai hibah.

\section{Simpulan}

Penjelasan yang telah diuraikan maka dapat disimpulkan bahwa tolok ukur hibah dapat diperhitungkan sebagai warisan adalah segala pemberian yang diberikan orang tua kepada anaknya yang tidak berhubungan dengan biaya pemeliharaan anak, baik pertumbuhan jasmani, rohani maupun yang berhungungan dengan pendidikan sang anak maka pemberian tersebut diperhitungkan sebagai warisan.

Terhadaptolok ukur hibah dari orang tua kepada anaknya diperhitungkan sebagai hibah adalah segala pemberian yang diberika orang tua kepada anaknya baik pemberian yang berhubungan dengan biaya pemeliharaan anak dan pendidikan anak juga pemberian-pemberian yang sifatnya tidak berhubungan dengan pemeliharaan anak dan juga pendidikan anak, yang sifatnya tidak mengharapkan imbalan atas pemberian tersebut, maka pemberian tersebut diperhitungkan sebagai hibah.

\section{Saran}

Diharapkan Pasal 211 Kompilasi Hukum Islam dapat diperjelas lagi agar tidak terjadi kekaburan 


\section{Analisis Kompilasi Hukum Islam Tentang Tolok Ukur Hibah yang Diperhitungkan sebagai Warisan}

Naviri Masma Rahmita \& Rachmad Budiono

norma mengenai Pasal 211 Komplasi Hukum Islam tersebut. Demikian pula diharapkan Kompilasi Hukum Islam ini tidak hanya sebatas Inpres saja melainkan disahkan sebagai Undang-Undang agar dapat dilaksanakan oleh seluruh masyarakat yang beragama Islam dalam menghadapi masalah terkait hukum Islam.

\section{DAFTAR PUSTAKA}

Afrizal. 2015. Pelaksanaan dan Status Hukum Pemberian Orang Tua Kepada Anak Perempuan Melalui Hareuta Peunulang Di Kabupaten Aceh Besar. Premisse Law Jurnal, Vol. 7. 1-17.

Ali,Mohammd Daud. 2007.Hukum Islam Pengantar Ilmu Hukum dan Tata Hukum Islam di Indonesia. Rajagrafindo Persada. Jakarta.

Al-Jaziri, Abdurrahman. 2007. Fikih Empat Mazhab (terjemahan dari Kitab al-Fiqh 'alâ Madzâhib alArba'ah. Rajawali Press. Jakarta.

Al-Jaziri, Abdurrahman. 2010.Kompilasi Hukum Islam. Akademika Pressindo. Jakarta.

Anshori,Abdul Ghiifur. 2012.Hukum Kewarisan Islamdi Indonesia Eksistensi dan Adaptabilitas.Gadjah Mada University Press. Yogyakarta.

Aziz,M. Abdul. 2008.Figh Muamalah. Pustaka Progresif. Yogyakarta.

Basyir,Ahmad Azhar. 1983, Hukum Adat Bagi Umat Islam. Nur Cahaya. Yogyakarta.

Basyir,Ahmad Azhar. 2001.Hukum Waris. UII Press. Yogyakarta.

Budiono,A.Rachmad. 1995.Pembaharuan Hukum Kewarisan Islam di Indonesia. Aditya Bakti. Bandung.

Chasana, LilikCholifatun. 2014. Penyelesaian Sengketa Hibah Terhadap Anak Angkat Melalui Kepala Desa, (Studikasus di DesaWangunKecPalangKabTuban). Thesis. Fakultas Syariah, Universitas Islam Negeri Maulana Malik Ibrahim. Malang.

Dahlan, Abdul Rahman. 2011.Ushul Figh.Bumi Aksara. Jakarta.
Djamil,Faturrahman. 1997.Falsafah Hukum Islam. Logos Wacana Ilmu. Jakarta.

Ibrahim, Johny. 2007. Teoridan Metodologi Penelitian Hukum Normatif. Bayu Media.Malang.

InstruksiPresidenRepublik Indonesia Nomor 1 Tahun 1991 tentangKompilasiHukum Islam. Jakarta.

Kitab Undang-Undang Hukum Perdata.

Lubis, Suhrawardi K. \& Komis Simanjutak. 2013.Hukum Waris Islam Lengkap dan Praktis. Sinar Grafika. Jakarta.

Praja,Juhaya S.1995.Filsafat Hukum Islam. LPPM. Bandung.

Purbasari,Indah. 2017.Hukum Islam Sebagai Hukum Positif di Indonesia. Setara Press. Malang.

Putusan Pengadilan Agama 13/Pdt.G/2012/P.A.Pts. Jakarta.

Ramulyo,M.Idris. 1994.Perbandingan Pelaksanaan Hukum Kewarisan Islam Dengan Kearisan Menurut Kitab Undang-Undang Hukum Perdata (BW).Sinar Grafika. Jakarta.

Sarmadi,H.A. Sukris. 2013.Hukum Waris Isam Indonesia Perbandingan Kompilasi Hukum Islam dan Fiqh Sunni.Aswaja Pressindo. Yogyakarta.

Sumitro, Warkum. 2016.Hukum Islam di Tengah Dinamika Sosial Politik di Indonesia. Setara Press. Malang.

Suparman, Eman. 1985.Intisari Hukum Waris Indonesia. Armico. Bandung.

Tanuwidjaya, Henny. 2012.Hukum Waris Menurut BW. Refika Aditama. Bandung.

Undang-UndangRepublik Indonesia Nomor12 Tahun 2011tentangPembentukanPeraturanPerundangUndangan. Jakarta.

\section{How to Cite:}

Rahmita, Naviri Masma \& Rachmad Budiono. 2017. Analisis Kompilasi Hukum Islam Tentang Tolok Ukur Hibah yang Diperhitungkan Sebagai Warisan. Jurnal Cakrawala Hukum. 8 (1): 75-85. 